\title{
Eruptive history of Karymsky volcano, Kamchatka, USSR, based on tephra stratigraphy and ${ }^{14} \mathrm{C}$ dating
}

\author{
OA Braitseva and IV Melekestsev
}

Institute of Volcanology, Academy of Sciences USSR, 9 Piip Boulevard, Petropavlovsk-Kamchatsky, 683006, USSR

Received March 21, 1990/Accepted August 20, 1990

\begin{abstract}
Eruptions of the active Karymsky stratovolcano began about $5300\left(6100{ }^{14} \mathrm{C}\right)$ B.P. from within a pre-existing caldera which formed $7700{ }^{14}$ C B.P. AS indicated by $32{ }^{14} \mathrm{C}$ determinations on buried soils and charcoal, the volcano has gone through two major cycles of activity, separated by a 2300 year period of repose. The first cycle can be divided into two stages (6100-5100 and 4300-2800 B.P.). The earlier stage began with especially intense eruptions of basaltic andesite to dacite. The later stage was characterized by moderate-strength eruptions of andesite. The second cycle, which is characterized by weak to moderate intermittent eruptions of andesite, started 500 B.P. and continues to the present. Eruptive patterns suggest that this cycle may continue for at least another 200 years with an eruptive character similar to that of the recent past.
\end{abstract}

\section{Introduction}

Karymsky volcano, constructed within the older Karymsky caldera (Figs. 1, 2), is among the most active in the eastern Kamchatka volcanic zone. Its symmetrical cone, virtually undissected by erosion, had an elevation of $1586 \mathrm{~m}$ in 1981. The summit crater changes size and shape from eruption to eruption (Magus'kin et al. 1982). The enclosing Karymsky caldera (5 x $6.5 \mathrm{~km}$ at the rim and $4 \times 5 \mathrm{~km}$ at the floor) is part of the Zhupanovsky volcano-tectonic depression in east-central Kamchatka, which contains several discrete nested calderas (Newhall and Dzurisin 1988).

The general geology of Karymsky volcano has been described by Vlodavets (1947), Ivanov (1970), and a research team (Masurenkov 1980). Its eruptive history has been interpreted by Braitseva, Yegorova, and Sulerzhitsky (1979; Masurenkov 1980), who used tephra stratigraphy and radiocarbon dating of tephra to determine the main stages of activity. More recently, the lava

Offprint requests to: OA Braitseva flows have been mapped, their age determined by radiocarbon methods, eruptive volumes calculated, and compositions determined for all major eruptions. These results permit use of the eruptive history for a longterm forecast of future activity.

\section{Study methods and main results}

\section{Tephra studies}

The general pyroclastic sequence (Fig. 3) is based on the study of 40 tephra sections from the flanks of the volcano. Two major pyroclastic assemblages are present: deposits of the caldera-forming eruption (KRM), and those of the later activity from Karymsky volcano (KM).

Pyroclastic deposits of the caldera-forming eruption are dacitic to rhyodacitic. The main horizons are (1) lower pumice-fall and pyroclastic flow deposits, (2) volcanic ash containing dispersed charcoal, and (3) upper lapilli-fall deposits (Braitseva et al. 1979; Masurenkov 1980). These tephra blanket all drainages both near the caldera and east to the ocean. The sections are similar everywhere, except for the decreasing thickness and coarseness of the tephra away from the center of eruption (Fig. 2). The pumiceous pyroclastic flow deposits have displayed thicknesses up to $70 \mathrm{~m}$ in river valleys. On valley sides, the lowest deposits are horizon 2 (volcanic ash containing charcoal), deposited from the ash clouds associated with the pyroclastic flows.

The tephra of Karymsky volcano can be divided into two groups, IKM and IIKM, which reflect two major cycles of activity. Intercalated buried soils are thin and rare within each tephra group, but they are separated by thick $(25 \mathrm{~cm})$ buried soils which contain only three tephra layers from Karymsky volcano and reflect a sustained period of reduced activity.

The pyroclastic deposits from Karymsky volcano vary in composition. Dominant andesitic tephra include (1) gray lithic volcanic sand and gravel and (2) intercalated white to yellow pumiceous tephra close to 


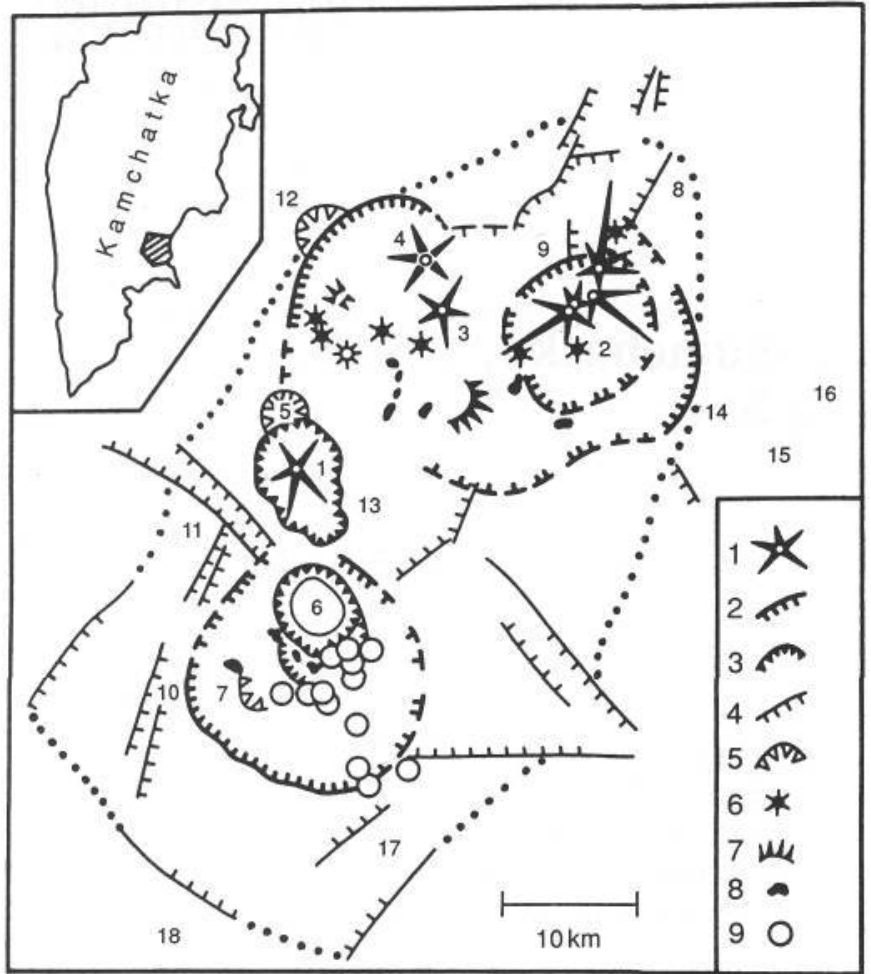

Fig. 1. Volcanoes of the Karymsky complex (from Newhall and Dzurisin 1988). Key to inset legend, with numbered symbols: 1 , modern volcanoes; 2 , caldera escarpments; 3 , position of the ring fractures of ancient and young caldera groups; 4, fractures expressed in topography of displaced blocks; 5 , explosion craters; 6 , cinder cones and lava domes; 7 , maar; 8 , extrusions; 9 , epicenters of volcano-tectonic earthquakes in 1975 with focal depths of $0-10$ $\mathrm{km}$. Key to numbers on map proper: 1, Karymsky volcano; 2, Maly Semiachik volcano; 3, Sukhoy; 4, Stupenchaty Bastion; 5, Dvor Caldera; 6, Akademii Nauk and Odnoboky calderas; 7, Beliankina; 8, Drevny Karymsky; 9, Semiachik caldera; 10, Krainy; 11, Razlaty; 12, Soboliny caldera; 13, Berezovy; 14, Stena caldera; 15, Pribezhny Yuzhny; 16, Pribezhny Severny; 17, Ditmara; 18, Zhupanovsky volcano-tectonic depression. Dotted line indicates approximate location of outer caldera rim

the cone and coarse ash at greater distances. In total, 12 horizons of light-colored pumiceous tephra can be distinguished (symbols $\mathrm{PM}_{1}-\mathrm{PM}_{12}$; Fig. 3), intercalated with thin, coarse ash horizons. Tephra of basaltic andesite occur as (1) deposits low in the sequence from early eruptions, i.e., stratified gray and greenish-gray volcanic sands with gravel, lapilli, and scoria bombs mixed with xenoliths of older rocks (fragments of lava, agglomerate tuffs, altered rocks), and (2) layers of porous black and brown scoria high in the sequence (layer SC), which are as much as 1-1.5 m thick on flanks of the volcano.

Karymsky volcano is the primary source for tephra in the region, but some thin tephra layers increase in thickness and coarseness toward Maly Semiachik volcano (Fig. 1). These are black and grayish-black scoriaceous sand and gravel (basalt to basaltic andesite in composition). Two layers of black sand high in the tephra sequence overlie group VIII lavas (400 B.p.), and several horizons are present within the soils that divide
KM from KPM deposits (not shown on Fig. 3). Thin tephra erupted from distant volcanoes are also present; their thickness and grain size are nearly constant across the Karymsky-Semiachinsky region. These are thin pink to pink-white ash, and yellow to gray volcanic sand (numbers 1-12 in Fig. 3).

\section{Dating the tephra: age of the volcano and caldera}

Times of eruptive activity were dated by radiocarbon methods, mainly on buried soil horizons and some charcoal from the soil or overlying tephra (Braitseva et al. 1989). For soils containing abundant humus, alkaline leachates of the sample were also dated. The range of dates gives information on the duration of soil formation and thus provides more precise ages for overlying and underlying tephra and for duration of repose periods. Dates from the flanks of Maly Semiachik volcano also were used. The results permit interpretation of the history of volcanic activity (Table 1). For the history of Karymsky volcano, we use a calibrated time scale based on the tables of Arslanov (1978). For the earlier part of the Holocene, for which corrections are still lacking, we use the uncorrected radiocarbon ages.

Karymsky caldera formed about $7700{ }^{14} \mathrm{C}$ B.P., as shown by several accordant dates on buried soil and charcoal from the lower lapilli horizon (Fig. 3). Two dates on charcoal from the pyroclastic flows and ashcloud deposits are considered to be older than their true age due to absorption by charcoal of $\mathrm{CO}$ from the hot gas-saturated deposits (Masurenkov 1980). The initial eruptions of Karymsky volcano, as determined by dating soil horizons underlying the lowest pyroclastic deposits, began about $6100\left(5300{ }^{14} \mathrm{C}\right)$ B.P.

\section{Ages of lava flows}

Eleven age groups of lava flows (I-XI) were separated with reference to the interlayered, radiometrically dated tephra (Fig. 3).

Group I flows, exposed only on the southeastern flank of the volcano (Fig. 4), are overlain by tephra horizon $\mathrm{PM}$, and its thin soil layer; they were erupted about $5400\left(4700{ }^{14} \mathrm{C}\right)$ B.P.

Group II flows, on the southern and southwestern flanks, are overlain by a buried soil and the $\mathrm{PM}_{2}$ tephra. They concluded the eruption at about 5100-5200 $\left(4400-4500{ }^{14} \mathrm{C}\right)$ B.P., which also erupted the $\mathrm{PM}_{3} \mathrm{pu}-$ mice.

Group III flows formed about $4300\left(3800{ }^{14} \mathrm{C}\right)$ B.P. They were erupted following deposition of a thin white ash layer during the start of the eruption, followed by coarse ash.

Group IV flows were erupted at about 4000 (3700 ${ }^{14}$ C) B.P., shortly after eruption of a gray ash and were covered by the $\mathrm{PM}_{3}$ pumice at the end of the same eruption.

Group V flows are overlain by stratified ash and then by the $\mathrm{PM}_{4}$ layer. Group VI flows overlie the $\mathrm{PM}_{5}$ 


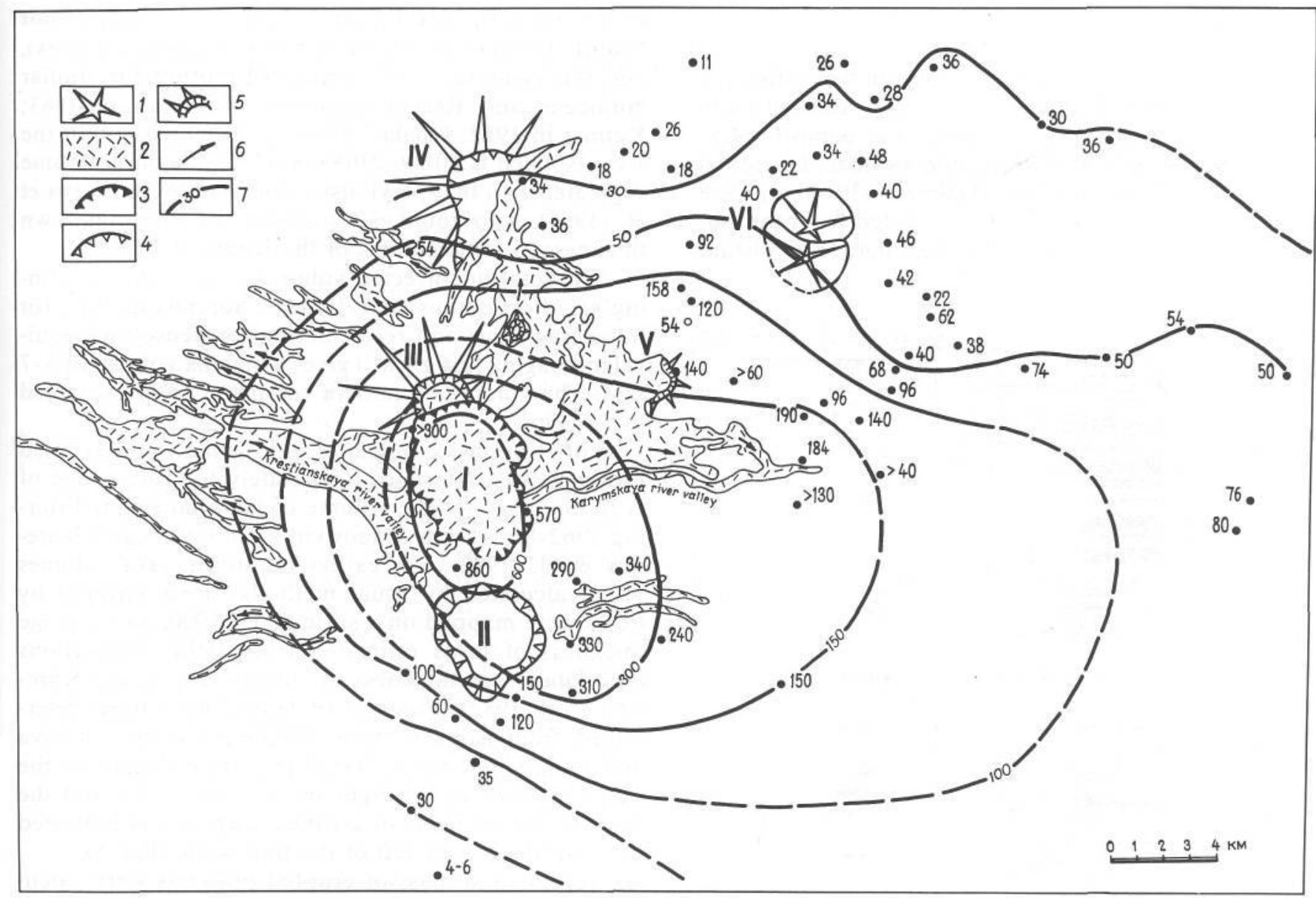

Fig. 2. Distribution of pyroclastic flows accompanying formation of Karymsky caldera and isopachs for tephra of the caldera-forming eruption. 1, pyroclastic flows; 2, stratovolcanoes; 3 , scarp of Karymsky caldera; 4, scarps of Upper Pleistocene-Holocene calderas; 5 , maars; 6 , direction of flow of pyroclastic flows; 7 , iso-

layer, but most underlie the soil or stratified volcanic sands which are beneath the SC layer. These two groups of flows have not been dated precisely: they are within the time interval from $2800\left(2600{ }^{14} \mathrm{C}\right)$ to 4100 $\left(3600{ }^{14} \mathrm{C}\right)$ B.P. We suggest that the age is approximately 3300-3400 B.P. for group V flows, and 3000-3100 B.P. for group VI flows.

Group VII flows lie immediately beneath the scoria layer SC and formed about $2800\left(2600{ }^{14} \mathrm{C}\right)$ B.P. This layer was deposited by distinctive pyroclastic flows containing dark andesitic bomblike scoria, some with dense cores.

Lava flows of groups VIII-IX were erupted during the last 500 years. The voluminous VIII lava flow and the group IX flows were erupted about 400 and 200250 B.P., respectively. Lava flow $\mathrm{X}$ is morphologically similar to historic flows, and considering its position under gray andesitic ash of the uppermost part of the sequence, could have formed during the eruption of 1934-1935. Lava flow VIII, which was assigned to this eruption by Vlodavets (1947), is considerably older according to our data, in agreement with Ivanov (1970). pachs of combined upper and lower lapilli horizons of the caldera-forming eruption, in $\mathrm{cm}$; numerical values listed for tephra observations points. I, Karymsky caldera; II, Maly Semiachik volcano; III, Soboliny volcano; IV, Karymsky Lake caldera

Group XI consists of flows from the 1962-1981 eruptions, described by Magus'kin et al. (1982) and Khrenov et al. (1982).

\section{Compositions}

Detailed petrology is beyond the scope of this study and will be reported separately. The general evolution of volcanic rocks and tephra is documented by analyses of tephra collected from each widespread layer and lavas from each age group (representative data in Table 2). Changes in $\mathrm{SiO}_{2}$ content are plotted in Fig. 3; plotted compositions of all pyroclastic samples are recalculated to be volatile free.

Pyroclastic deposits of the caldera-forming eruption are dacite and rhyodacite. Lavas and pyroclastics of Karymsky volcano are mostly andesite (57-64\% $\left.\mathrm{SiO}_{2}\right)$; dacite (to $65 \% \mathrm{SiO}_{2}$ ) is present only among group-II lavas. The initial pyroclastics and the 2800 B.P. SC tephra are basaltic andesite $\left(52-56 \% \mathrm{SiO}_{2}\right)$. 


\section{Volumes}

The volume of caldera-forming eruption was estimated by adding volumes of pyroclastic flow deposits and tephra. The volume of pyroclastic flow deposits (4.5$6 \mathrm{~km}^{3}$ ) was determined using the estimated original area $\left(150 \mathrm{~km}^{2}\right)$ and average thickness $(30-40 \mathrm{~m})$. The tephra volume $\left(8-10 \mathrm{~km}^{3}\right)$ was calculated from the isopach map of the study area, thickness data from distant

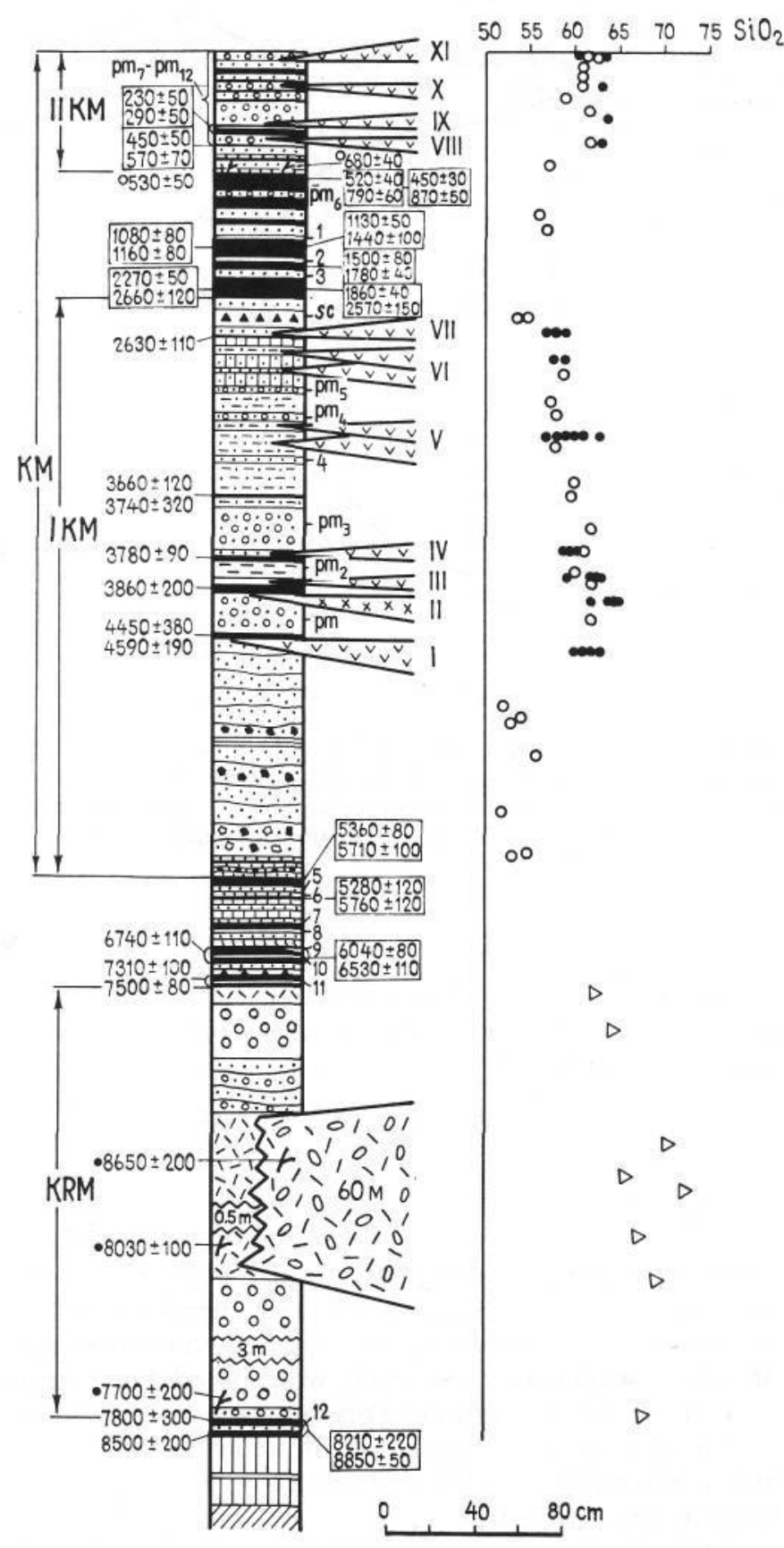

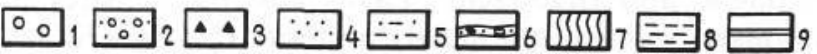

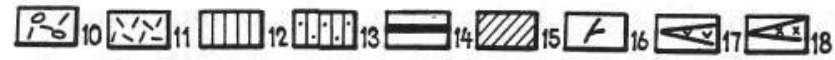
88: $1982.820 \pm 5020$ points in the Eastern Volcanic Zone and the Komandor Islands (500 km northeast of the Karymsky complex), and the systematics of tephra distribution for similar Holocene and Recent eruptions (Krakatau in 1883; Katmai in 1912; Opala 1500 B.P). The area within the $1-\mathrm{cm}$ isopach is $40000-50000 \mathrm{~km}^{2}$. This tephra volume is greater than that previously estimated by Braitseva et al. (1985), who could not consider the then unknown thickness in remote areas of the Komandor Islands.

The total uncorrected volume of the caldera-forming eruption is thus $12.5-16 \mathrm{~km}^{3}$. Subtracting $10 \%$ for lithic fragments and recalculating for dense-rock-equivalent magma $\left(2.4 \mathrm{~g} / \mathrm{cm}^{3}\right)$ gives a magma volume of 5-7 $\mathrm{km}^{3}$. The volume of caldera collapse is also estimated as $5-7 \mathrm{~km}^{3}$.

For Karymsky volcano, the volume of erupted products was determined separately for each stage of eruption (Fig. 5). The volume of material erupted during 1962-81 is from Magus'kin et al. (1982) and Khrenov et al. (1982). For earlier eruptions, lava volumes were calculated by usual methods: areas covered by flows were mapped on a scale of 1:10000, and average thickness of lavas estimated from field observations and data about thickness of similar lava flows (Khrenov et al. 1982). Volumes of tephra have been determined from isopach maps. Relative volumes of lava and tephra for specific eruptions are reflected in the size of arrows to the right of the time scale, and the mass of the products of greatest eruptions is indicated by bold lines to the left of the time scale (Fig. 5).

Volume and mass of erupted products were calculated for the two major volcanic cycles (IKM and IIKM) and also for separate stages and eruptive phases of the IKM cycle (Table 3, Fig. 3). Eruptive volumes for the IIKM cycle and stages of the IKM cycle were determined directly from the volumes of their pyroclastics

Fig. 3. Composite cross section of lavas and pyroclastic deposits on the flanks of Karymsky volcano. 7, bombs and pumice lapilli; 2 , pumice lapilli with volcanic sand; 3 , scoria lapilli with volcanic sand; 4, volcanic sand, nonstratified; 5 , stratified volcanic sand; 6 , stratified pyroclastics of initial volcanic eruptions of the volcano, volcanic sands; the same sands with lapilli, bombs and admixed xenolithic material; 7 , volcanic sands, ochered; 8 , volcanic sands and fine ashes, stratified; 9, intercalated fine sands; 10, pyroclastic flow deposits; 77, fine ash from ash-clouds of the caldera-forming eruption; 12, sandy soils; 13, sandy soils with admixed volcanic sands; 14 , buried soils; 75 , pre-karymsky deposits; 16, wood and charcoal; 17 , andesitic lava flows; 75 , andesitic and dacitic lava flows; 19, data points for chemical compositions: a, tephra of Karymsky volcano; b, lavas of the same volcano; c, pyroclastics of the caldera-forming eruption (compositions of a and $\mathrm{b}$ are recalculated volatile free); 20 , radiocarbon dates; a, from wood; $b$, from charcoal; others from buried soils (in the framework of dates for alkaline leachates from the same soil sample). KPM, deposits associated with formation of Karymsky caldera; IKM, IIKM, main periods of activity of Karymsky volcano; I-XI, groups of lava flows; $\mathrm{PM}_{1}-\mathrm{PM}_{12}$, pumiceous tephra horizons; $\mathrm{SC}$, intercalated scoria. 1-12, Tephra from distant sources (layer 2, from Opala volcano; 3, from Ksudach volcano; layers 4-5, from Avacha volcano; layer 10, from Khangar volcano; layer 11, from Kizimen volcano; for other layers, the source is not presently known) 
Table 1. Eruptive history of Karymsky volcano

\begin{tabular}{|c|c|c|c|c|c|c|}
\hline & $\begin{array}{l}\text { Soil-pyroclastic cover depos- } \\
\text { its at the foot of volcano }\end{array}$ & $\begin{array}{l}\text { Lava } \\
\text { flows }\end{array}$ & $\begin{array}{l}\text { Composition } \\
\text { of products }\end{array}$ & $\begin{array}{l}\text { Age borders, } \\
\text { years ago }\end{array}$ & Style of volcanic activity & $\begin{array}{l}\text { Up- } \\
\text { surge } \\
\text { periods }\end{array}$ \\
\hline \multirow{9}{*}{$\begin{array}{l}\text { Karymsky } \\
\text { volcano }\end{array}$} & $\begin{array}{l}\text { Layers of pumice tephra } \\
\left(\mathrm{PM}_{7}-\mathrm{PM}_{12}\right) \text { and gray coarse } \\
\text { ashes, separated by thin } \\
\text { layers of buried soils }\end{array}$ & $\begin{array}{l}\text { XI } \\
\text { X } \\
\text { IX } \\
\text { VIII }\end{array}$ & andesite & \multirow{2}{*}{500} & $\begin{array}{l}\text { Upsurge of volcanic activity frequent } \\
\text { effusive-explosive eruptions, separated } \\
\text { by short repose period }\end{array}$ & II KM \\
\hline & $\begin{array}{l}\text { Soil with coarse ash and pu- } \\
\text { mice tephra interlayers the } \\
\text { upper part } \mathrm{PM}_{6}\end{array}$ & & andesite & & $\begin{array}{l}\text { Repose period with single slight explo- } \\
\text { sive eruptions at the end of period }\end{array}$ & \\
\hline & $\begin{array}{l}\text { Bombs and cinder lapilli, } \\
\text { coarse ash }\end{array}$ & & $\begin{array}{l}\text { basaltic } \\
\text { andesite }\end{array}$ & \multirow{2}{*}{2800} & Strong explosive eruption & \multirow{5}{*}{ I KM } \\
\hline & $\begin{array}{l}\text { Stratified coarse gray ashes, } \\
\text { interlayers of pumice tephra } \\
\mathrm{PM}_{4} \text { and } \mathrm{PM}_{5}\end{array}$ & $\begin{array}{l}\text { VII } \\
\text { VI } \\
\text { V }\end{array}$ & andesite & & $\begin{array}{l}\text { Intense explosive-effusive activity, fur- } \\
\text { ther growth of the volcano cone }\end{array}$ & \\
\hline & $\begin{array}{l}\text { Pumice bombs and lapilli, } \\
\text { coarse ash }\left(\mathrm{PM}_{1} \text { and } \mathrm{PM}_{3}\right)\end{array}$ & $\begin{array}{l}\text { IV } \\
\text { III }\end{array}$ & & $\begin{array}{l}4100 \\
4200\end{array}$ & Two large explosive-effusive eruptions & \\
\hline & $\begin{array}{l}\text { thin and coarse ashes }\left(\mathrm{PM}_{2}\right) \\
\text { separated by interlayers of } \\
\text { soils }\end{array}$ & II & $\begin{array}{l}\text { dacite, } \\
\text { andesite }\end{array}$ & 5100 & $\begin{array}{l}800 \text {-year-long repose period } \\
\text { Intense explosive-effusive eruption }\end{array}$ & \\
\hline & $\begin{array}{l}\text { Stratified coarse ashes sepa- } \\
\text { rated layers with lapilli and } \\
\text { bombs, admixture of resur- } \\
\text { gents material }\end{array}$ & $\begin{array}{l}\text { I } \\
?\end{array}$ & $\begin{array}{l}\text { andesite, } \\
\text { Basaltic } \\
\text { andesite }\end{array}$ & & $\begin{array}{l}\text { Onset of formation of Karymsky volca- } \\
\text { no: the cone growth, intense explosive } \\
\text { activity, lava flow outpouring }\end{array}$ & \\
\hline & $\begin{array}{l}\text { Bench of buried soils with } \\
\text { tephra of Maly Semyachik } \\
\text { volcano and with interlayers } \\
\text { of transite ashes }\end{array}$ & & & 6100 & Repose period & \\
\hline & $\begin{array}{l}\text { Bombs and lapilli of pumice, } \\
\text { coarse and thin ash, pyroclas- } \\
\text { tic deposits }\end{array}$ & & $\begin{array}{l}\text { dacite, } \\
\text { Rhyodacite }\end{array}$ & ${ }^{14} \mathrm{C}$ & $\begin{array}{l}\text { Caldera-forming eruptions: pumice } \\
\text { ejections, pyroclastic flows, collapse } \\
\text { caldera formation }\end{array}$ & KRM \\
\hline
\end{tabular}

and lavas: lava volumes are the sums of volumes of lava flows formed during each stage or cycle, and the volume of pyroclastic material was calculated for each cycle using the corresponding isopach map. The volume of pyroclastics within the cone has been considered to compose about $40 \%$ of the total tephra volume (Braitseva et al. 1984). The volume of volcanic products of the IKM cycle (and its beginning stage $\mathrm{IKM}_{1}$ were determined as the difference between the total volume of volcanic products and the sum of volumes erupted during these stages. The total volume of volcanic products $\left(6.3 \mathrm{~km}^{3}\right)$ is the combined volume of the volcanic cone $\left(2.9 \mathrm{~km}^{3}\right)$, tephra $\left(1 \mathrm{~km}^{3}\right)$, and caldera-filling deposits above the level of the lake inferred to have filled the caldera $\left(2.4 \mathrm{~km}^{3}\right)$. This caldera fill can be approximated as the volume of the segment of a sphere with area of $19 \mathrm{~km}^{2}$ and height of $0.25 \mathrm{~km}$. In evaluating the mass of erupted products (in accord with data from the literature), the specific gravity of andesitic lava flows was taken as $2-2.2 \mathrm{~g} / \mathrm{cm}^{3}$, andesitic and andesite-dacitic tuffs as $1.1-1.3 \mathrm{~g} / \mathrm{cm}^{3}$, dacitic pyroclastics of the caldera-forming eruption as $1 \mathrm{~g} / \mathrm{cm}^{3}$, and compacted pyroclastics of the volcano as $1.5-1.7 \mathrm{~g} / \mathrm{cm}^{3}$.

\section{Volcanic history and eruptive dynamics}

A strong caldera-forming eruption began at the Karymsky center about $7700{ }^{14} \mathrm{C}$ B.P. It started with massive outbursts of pumiceous tephra ("lower lapilli"), which rest directly on the underlying soil. Blast deposits are absent in these lower tephra, even close to the caldera. The main axis of tephra fall is ESE. The tephra fall was succeeded by pyroclastic flows, which mainly followed valleys of the Krestyanskaya and Karymskaya rivers (Fig. 2). Ash clouds which accompanied the pyroclastic flows spread thin ash veneers over large areas. Immediately after eruption of the pyroclastic flows, explosive outbursts generated additional ash falls, the coarsest of which is the "upper lapilli" layer (Fig. 3). The depositional axis of this ash fall is ENE. The combined thickness of the lower and upper tephra near the Karymsky center is shown in Fig. 2; the thickness of tephra reaches $3 \mathrm{~cm}$ on Bering Island, the easternmost of the Komondor Islands (Kirianov and Yegorova, 1986). In size of caldera collapse and the volume of erupted material $\left(12.5-16 \mathrm{~km}^{3}\right)$, this caldera-forming 

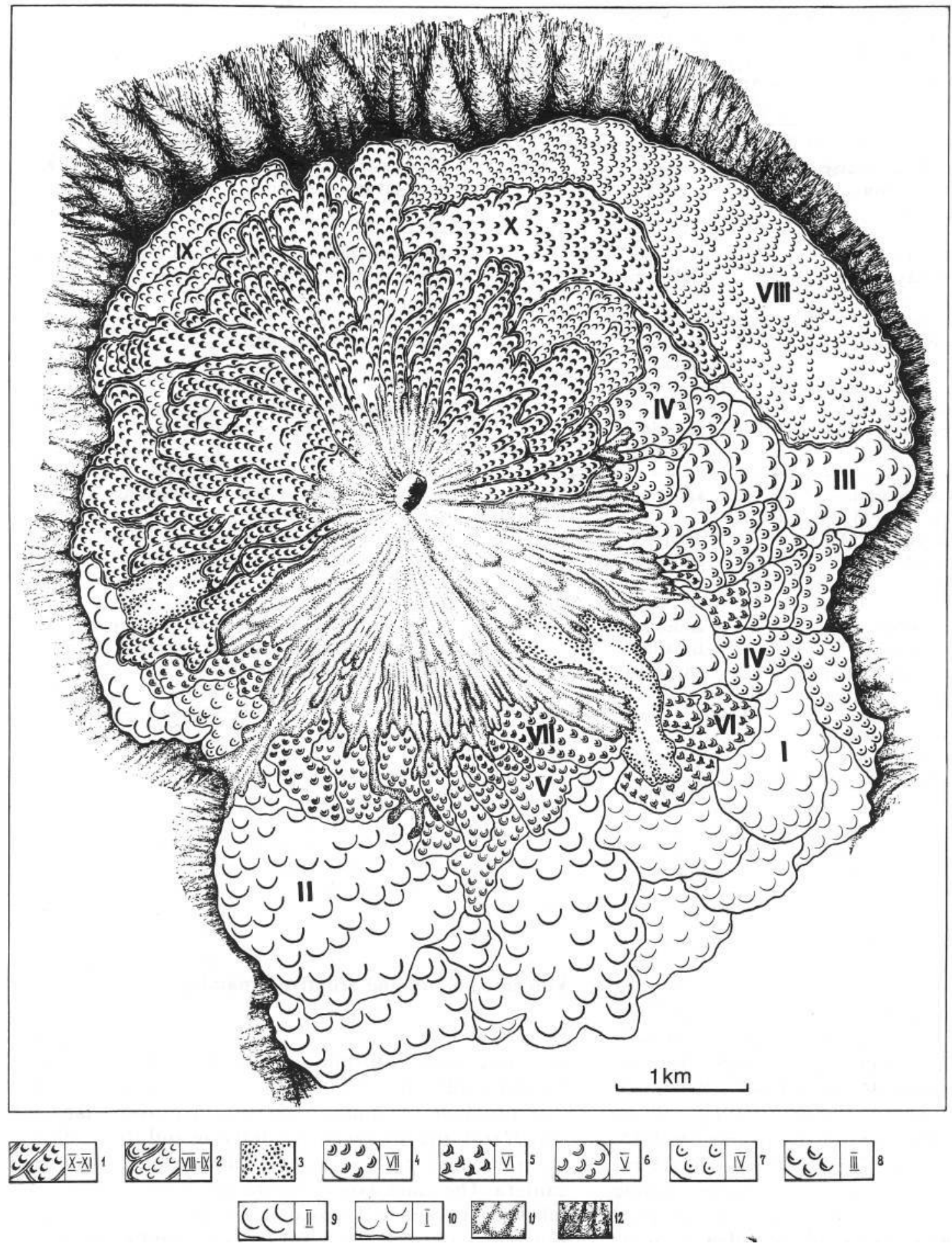

Fig. 4. Map of lava flow groups on Karymsky volcano. 1, andesitic flows of historic eruptions (XI, 1962-1980; X, 1931-193?); 2, andesitic flows IX (200-250 B.P.) and VIII (400 B.P.); 3, pyroclastic scoria avalanche deposits (about 2800 в.p.); 4, andesitic flows VII (2800 B.P.); 5, andesitic flows VI (3000-3100 B.P.); 6, andesitic

eruption was comparable to the famous Krakatau eruption in 1883 .

After formation of the caldera, volcanic activity ceased for at least 1600 years, as expressed by buried soils which contain only ash layers from Maly Semia- flows V (3300-3400 B.P); 7, andesitic flows IV (4200 B.P.); 8, andesitic flows III (4300 B.P.); 9, dacitic and andesitic flows II (5100-5200 B.P.); 10, andesitic lows I (about 5400 B.P.); 11, pyroclastic deposits of the volcanic cone and pyroclastic avalanches of historic eruptions; 12 , caldera rim

chik volcano (Fig. 1) and other distant sources. Alluvial-fan and lacustrine deposits, which probably accumulated within the caldera during this period, are mostly now covered by lavas of Karymsky volcano. A remnant of the lake bottom is probably represented by 
Table 2. The chemistry of lavas and tephra of Karymsky and its eruption associated with the Karymsky Caldera formation

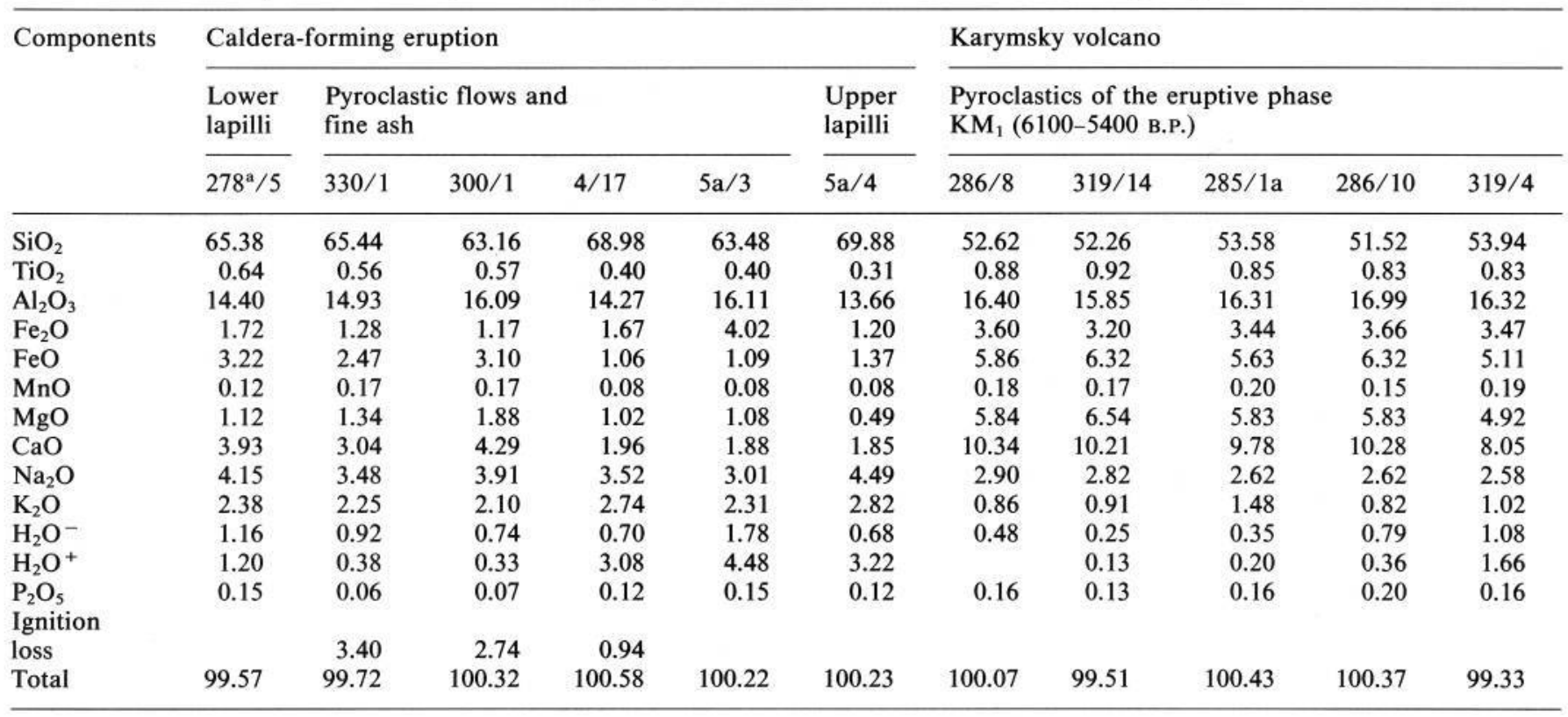

Period of increased activity I KM (6100-2800 yrs ago)

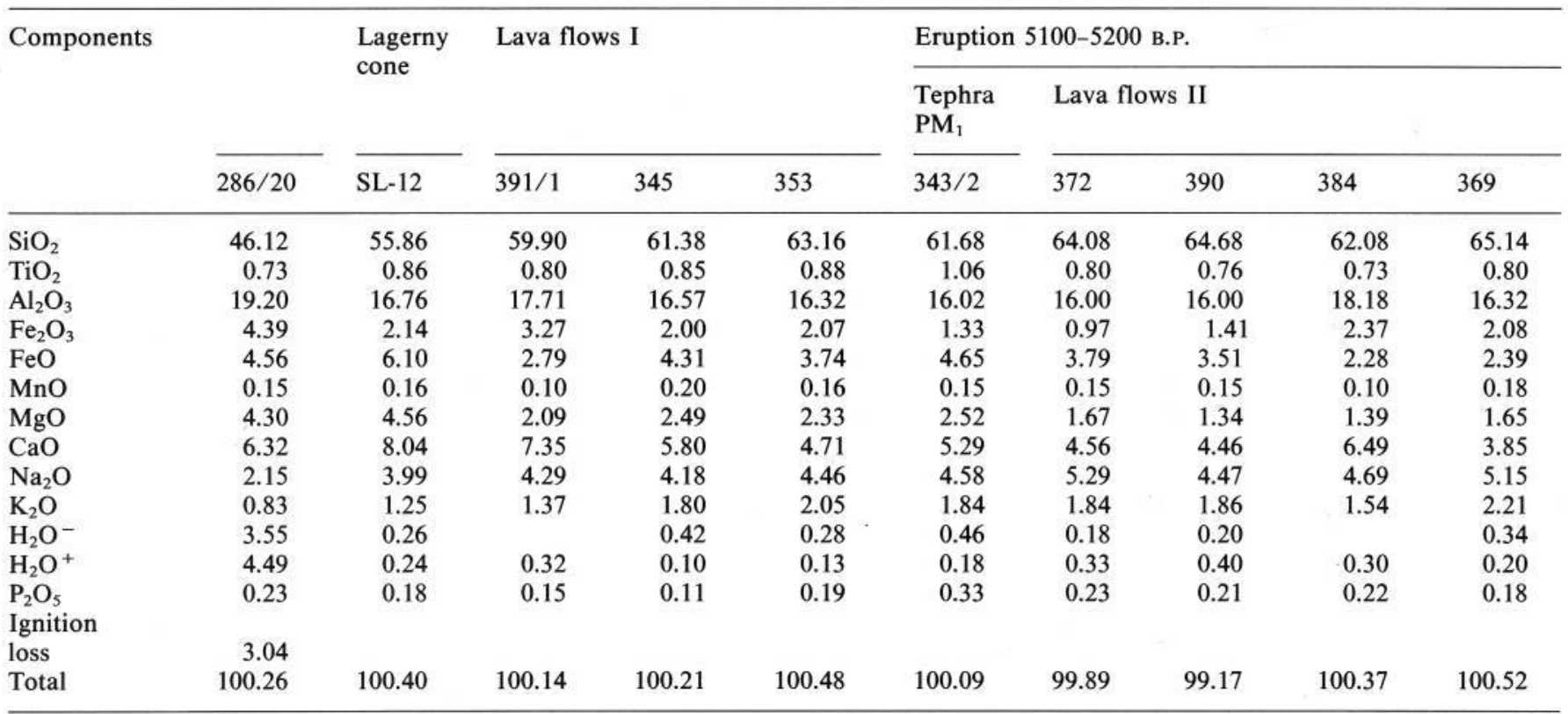

the plain in the southern part of caldera depression, where thermal springs occur in the Karymskaya river valley.

Karymsky volcano started to grow within the caldera about $5300\left(6100{ }^{14} \mathrm{C}\right)$ B.P. Its history can be divided into two main cycles, i.e., IKM and IIKM (not yet complete), divided by a 2300 -year repose period. During the IKM cycle, in turn, two stages of activity are divided by an inactive period of about 800 years (Fig. 3, Table 1).

Early during the IKM cycle (eruptive stage $\mathrm{IKM}_{1}$; Fig. 5), the caldera was filled and a volcanic cone was built. The character of tephra indicates that eruptions were frequent but weak. (Strong eruptions of Karymsky volcano are defined as those involving 0.5-0.05 x $10^{9}$ tonnes of material, and weak eruptions as those of less than $0.05 \times 10^{9}$ tonnes.) The tephra are mainly basaltic andesite (52-56\% $\mathrm{SiO}_{2}$ content, Table 3, Fig. 3). No lava flows of this composition are exposed on flanks of the volcano; any that were erupted are buried by younger material. Lava of this composition is present at the small lava cone "Lagerny" in the southern part of caldera. Tephra correlations indicate that this cone was active concurrently with initial activity at Karymsky volcano, i.e., basaltic andesite vented through several conduits, not only through Karymsky volcano. In the 
Table 2. (continued)

\begin{tabular}{|c|c|c|c|c|c|c|c|c|c|c|}
\hline \multicolumn{11}{|c|}{ Period of increased activity I KM (6100-2800 yrs ago) } \\
\hline \multirow{3}{*}{ Components } & \multicolumn{5}{|c|}{ Eruption 4300 yrs ago } & \multicolumn{5}{|c|}{ Eruption 4200 yrs ago } \\
\hline & \multirow{2}{*}{$\begin{array}{l}\text { Tephra } \\
\mathrm{PM}_{2} \\
348 / 1\end{array}$} & \multicolumn{3}{|c|}{ Lava flows III } & \multirow{2}{*}{$\begin{array}{l}\text { Tephra } \\
278 / 33\end{array}$} & \multirow{2}{*}{$\begin{array}{l}\text { Tephra } \\
278 / 30\end{array}$} & \multicolumn{3}{|c|}{ Lava flows IV } & \multirow{2}{*}{$\begin{array}{l}\text { Tephra } \\
\mathrm{PM}_{3} \\
278 / 29\end{array}$} \\
\hline & & 411 & 422 & $413 / 1$ & & & 407 & 421 & 381 & \\
\hline $\mathrm{SiO}_{2}$ & 60.88 & 63.00 & 61.98 & 59.08 & 59.62 & 60.58 & 60.08 & 59.16 & 59.50 & 59.84 \\
\hline $\mathrm{TiO}_{2}$ & 0.88 & 0.88 & 0.91 & 0.80 & 0.81 & 0.64 & 0.87 & 0.82 & 0.53 & 0.83 \\
\hline $\mathrm{Al}_{2} \mathrm{O}_{3}$ & 16.68 & 16.32 & 15.94 & 16.62 & 16.84 & 17.75 & 16.32 & 16.67 & 16.53 & 16.94 \\
\hline $\mathrm{Fe}_{2} \mathrm{O}_{3}$ & 2.43 & 3.42 & 1.31 & 1.84 & 2.93 & 2.68 & 2.32 & 2.84 & 2.12 & 2.23 \\
\hline $\mathrm{FeO}$ & 3.68 & 2.10 & 4.88 & 5.60 & 4.36 & 3.10 & 4.48 & 4.60 & 4.42 & 3.59 \\
\hline $\mathrm{MnO}$ & 0.17 & 0.16 & 0.24 & 0.15 & 0.14 & 0.14 & 0.19 & 0.13 & 0.17 & 0.17 \\
\hline $\mathrm{MgO}$ & 2.27 & 2.01 & 1.53 & 2.74 & 3.20 & 2.18 & 3.66 & 2.90 & 3.03 & 2.07 \\
\hline $\mathrm{CaO}$ & 5.48 & 4.56 & 4.86 & 7.03 & 5.78 & 5.97 & 6.06 & 7.30 & 6.49 & 5.23 \\
\hline $\mathrm{Na}_{2} \mathrm{O}$ & 4.64 & 4.67 & 4.28 & 3.86 & 4.08 & 4.27 & 4.08 & 3.99 & 4.33 & 4.28 \\
\hline $\mathrm{K}_{2} \mathrm{O}$ & 1.75 & 2.05 & 1.73 & 1.37 & 1.45 & 1.56 & 1.56 & 1.54 & 1.77 & 1.63 \\
\hline $\mathrm{H}_{2} \mathrm{O}^{-}$ & 0.36 & 0.32 & 0.13 & 0.24 & 0.57 & 0.70 & 0.25 & - & - & 1.36 \\
\hline $\mathrm{H}_{2} \mathrm{O}^{+}$ & 1.00 & 0.42 & 0.33 & 0.36 & 0.17 & 0.51 & 0.46 & - & - & 1.18 \\
\hline $\begin{array}{l}\mathrm{P}_{2} \mathrm{O}_{5} \\
\text { Ignition }\end{array}$ & 0.22 & 0.23 & 0.19 & 0.31 & 0.19 & 0.18 & 0.12 & 0.19 & 0.19 & 0.20 \\
\hline loss & & & & & & & & & & 0.44 \\
\hline Total & 100.41 & 100.14 & 99.72 & 100.00 & 100.14 & 100.26 & 100.45 & 100.14 & 99.63 & 99.99 \\
\hline
\end{tabular}

Period of increased activity $1 \mathrm{KM}(6100-2800$ yrs ago)

\begin{tabular}{|c|c|c|c|c|c|c|c|c|c|c|}
\hline \multirow[t]{3}{*}{ Components } & \multicolumn{10}{|c|}{ Deposits of eruptive phase $\mathrm{KM}_{2}(4100-2800 \mathrm{yrs}$ ago) } \\
\hline & \multicolumn{3}{|l|}{ Tephra } & \multicolumn{4}{|c|}{ Lava flows $\mathrm{V}$} & \multirow{2}{*}{$\begin{array}{l}\text { Tephra } \\
\mathrm{PM}_{4} \\
285 / 6\end{array}$} & \multicolumn{2}{|c|}{ Tephra } \\
\hline & $285 / 11$ & $285 / 10$ & $285 / 8$ & 350 & 349 & 358 & 351 & & $285 / 5$ & $285 / 3$ \\
\hline $\mathrm{SiO}_{2}$ & 58.26 & 58.74 & 56.76 & 57.24 & 59.12 & 61.04 & 63.12 & 57.24 & 56.36 & 58.24 \\
\hline $\mathrm{TiO}_{2}$ & 0.83 & 0.83 & 0.85 & 0.90 & 0.74 & 0.82 & 0.85 & 0.89 & 0.89 & 0.92 \\
\hline $\mathrm{Al}_{2} \mathrm{O}_{3}$ & 16.56 & 16.76 & 18.29 & 17.08 & 16.28 & 16.83 & 16.61 & 16.62 & 17.06 & 16.91 \\
\hline $\mathrm{Fe}_{2} \mathrm{O}_{3}$ & 2.30 & 2.98 & 2.15 & 2.45 & 2.01 & 2.07 & 1.87 & 3.07 & 2.56 & 2.41 \\
\hline $\mathrm{FeO}$ & 4.31 & 4.11 & 4.89 & 5.89 & 5.17 & 2.23 & 3.65 & 4.14 & 4.94 & 4.83 \\
\hline $\mathrm{MnO}$ & 0.17 & 0.11 & 0.13 & 0.21 & 0.15 & 0.08 & 0.18 & 0.11 & 0.13 & 0.20 \\
\hline $\mathrm{MgO}$ & 3.96 & 3.40 & 4.47 & 3.64 & 2.87 & 1.47 & 2.37 & 4.74 & 4.02 & 3.79 \\
\hline $\mathrm{CaO}$ & 6.51 & 6.25 & 5.50 & 7.52 & 6.85 & 6.64 & 4.79 & 6.63 & 7.22 & 6.73 \\
\hline $\mathrm{Na}_{2} \mathrm{O}$ & 3.60 & 3.69 & 3.75 & 3.65 & 4.50 & 4.59 & 4.46 & 3.51 & 3.47 & 3.65 \\
\hline $\mathrm{K}_{2} \mathrm{O}$ & 1.35 & 1.35 & 1.31 & 1.50 & 1.44 & 1.56 & 1.88 & 1.35 & 1.31 & 1.35 \\
\hline $\mathrm{H}_{2} \mathrm{O}^{-}$ & 0.59 & 0.68 & 0.46 & 0.28 & 0.18 & 0.02 & 0.26 & 0.82 & 0.62 & 0.81 \\
\hline $\mathrm{H}_{2} \mathrm{O}^{+}$ & 1.07 & 0.39 & 1.47 & - & 0.30 & 0.76 & 0.10 & 0.30 & 0.77 & 0.56 \\
\hline $\mathrm{P}_{2} \mathrm{O}_{5}$ & 0.09 & 0.12 & 0.19 & 0.08 & 0.37 & 0.07 & 0.21 & 0.11 & 0.22 & 0.09 \\
\hline Total & 99.60 & 99.41 & 97.92 & 100.44 & 99.98 & 100.18 & 100.35 & 99.53 & 99.56 & 100.49 \\
\hline
\end{tabular}

middle of the $\mathrm{IKM}_{1}$ stage, the composition changed to more silicic andesite, and group I lava flows were erupted (volume about $0.25 \mathrm{~km}^{2}$ ). After a 300 -year-long recess of volcanic activity, a strong eruption $\left(\mathrm{PM}_{1}\right.$ tephra, group II lavas) took place at 5200-5100 (4500-4400 ${ }^{14}$ C) B.P. Tephra of this eruption are widespread eastward (Fig. 6), where this horizon serves as a marker (Braitseva et al. 1985). Lava flows of this eruption are the thickest on the volcano (up to $80 \mathrm{~m}$ ); they almost completely filled the southeast part of the caldera. These flows are characterized by contrast in microrelief with large and extensive transverse ridges. This concluding eruption of the first eruptive stage $\left(\mathrm{IKM}_{1}\right)$ was the strongest in the entire history of the volcano (Table 3, Fig. 5).

After 800 years of repose, activity of the volcano resumed with two moderate-strength eruptions $\left(\mathrm{PM}_{2}\right.$-III, $\mathrm{PM}_{2}$-IV) at the beginning of stage $\mathrm{IKM}_{2}$ at about 4300 $\left(3800{ }^{14} \mathrm{C}\right)$ B.P. and $4200\left(3700{ }^{14} \mathrm{C}\right)$ B.P. Both eruptions were only about a quarter as strong as the culminating eruption of the preceding stage (Fig. 3, Table 3), but tephra of the $\mathrm{PM}_{3}$ are comparable in volume with tephra of $\mathrm{PM}_{1}$. The axis of the ash fall of this eruption was westward (Fig. 6).

Following these comparatively strong eruptions, further eruptive activity of the $\mathrm{IKM}_{2}$ stage was similar 
Table 2. (continued)

\begin{tabular}{|c|c|c|c|c|c|c|c|c|c|}
\hline \multicolumn{8}{|c|}{ Period of increased activity I KM (6100-2800 B.P.) } & \multirow{3}{*}{\multicolumn{2}{|c|}{$\begin{array}{l}\text { Tephra in soil during } \\
\text { repose period }\end{array}$}} \\
\hline \multirow[t]{3}{*}{ Components } & \multicolumn{7}{|c|}{ Deposits of eruptive phase $\mathrm{KM}_{2}$ (4100-2800 B.P.) } & & \\
\hline & \multicolumn{2}{|c|}{ Lava flows VI } & \multicolumn{3}{|c|}{ Lava flows VII } & \multirow{2}{*}{$\frac{\begin{array}{l}\text { Scoria } \\
\text { avalanche }\end{array}}{429}$} & \multirow{2}{*}{$\begin{array}{l}\text { Tephra } \\
\text { sc }\end{array}$} & & \\
\hline & 428 & 418 & 368 & 356 & 397 & & & $283 / 13$ & $278 / 13$ \\
\hline $\mathrm{SiO}_{2}$ & 58.06 & 59.26 & 58.14 & 57.42 & 59.02 & 56.78 & 53.26 & 56.08 & 65.84 \\
\hline $\mathrm{TiO}_{2}$ & 0.80 & 0.81 & 0.83 & 0.93 & 0.85 & 0.85 & 1.00 & 1.05 & 0.83 \\
\hline $\mathrm{Al}_{2} \mathrm{O}_{3}$ & 16.35 & 17.14 & 16.63 & 17.31 & 16.40 & 16.65 & 16.52 & 16.85 & 17.72 \\
\hline $\mathrm{Fe}_{2} \mathrm{O}_{3}$ & 2.13 & 1.77 & 2.47 & 2.51 & 0.81 & 2.53 & 5.34 & 2.97 & 2.24 \\
\hline $\mathrm{FeO}$ & 4.34 & 4.94 & 4.25 & 5.03 & 5.89 & 5.75 & 4.25 & 5.48 & 5.14 \\
\hline $\mathrm{MnO}$ & 0.20 & 0.18 & 0.25 & 0.20 & 0.17 & 0.11 & 0.23 & 0.18 & 0.18 \\
\hline $\mathrm{MgO}$ & 4.21 & 3.39 & 4.98 & 4.03 & 3.08 & 3.68 & 4.49 & 3.45 & 3.52 \\
\hline $\mathrm{CaO}$ & 6.99 & 6.80 & 6.92 & 6.96 & 6.91 & 7.97 & 9.13 & 7.59 & 7.61 \\
\hline $\mathrm{Na}_{2} \mathrm{O}$ & 3.92 & 4.00 & 3.27 & 3.79 & 4.39 & 3.84 & 3.26 & 3.65 & 3.38 \\
\hline $\mathrm{K}_{2} \mathrm{O}$ & 1.45 & 1.54 & 1.57 & 1.38 & 1.36 & 1.50 & 0.79 & 1.36 & 1.26 \\
\hline $\mathrm{H}_{2} \mathrm{O}^{-}$ & - & - & - & 0.46 & 0.28 & - & 0.45 & 0.53 & 0.99 \\
\hline $\mathrm{H}_{2} \mathrm{O}^{+}$ & 1.18 & 0.04 & 0.40 & 0.25 & 0.44 & - & - & 0.08 & 0.77 \\
\hline $\begin{array}{l}\mathrm{P}_{2} \mathrm{O}_{5} \\
\text { Ignition }\end{array}$ & 0.16 & 0.23 & 0.17 & 0.12 & 0.21 & 0.14 & 0.20 & 0.23 & 0.20 \\
\hline loss & & & & & & & 1.00 & 0.61 & \\
\hline Total & 99.79 & 100.10 & 99.83 & 100.39 & 99.81 & 99.80 & 99.92 & 100.111 & 99.68 \\
\hline
\end{tabular}

Period of increased activity II KM 500 B.P. - present time

\begin{tabular}{|c|c|c|c|c|c|c|c|c|c|c|}
\hline \multirow[t]{3}{*}{ Components } & \multirow[t]{2}{*}{ Tephra } & \multicolumn{2}{|c|}{ Eruption 400 yrs ago } & \multicolumn{2}{|c|}{ Eruption 200 B.P. } & \multirow{2}{*}{$\begin{array}{l}\text { Tephra } \\
\text { PM }_{10}\end{array}$} & \multicolumn{2}{|c|}{ Eruption $1935 ?$} & \multirow[t]{2}{*}{ Tephra } & \\
\hline & & $\begin{array}{l}\text { Tephra } \\
\mathrm{PM}_{7}\end{array}$ & $\begin{array}{l}\text { Lava } \\
\text { VIII }\end{array}$ & $\begin{array}{l}\text { Lava } \\
\text { IX }\end{array}$ & $\begin{array}{l}\text { Tephra } \\
\mathrm{PM}_{9}\end{array}$ & & $\begin{array}{l}\text { Tephra } \\
\text { PM }_{11}\end{array}$ & $\begin{array}{l}\text { Lava } \\
\mathrm{X}\end{array}$ & & \\
\hline & $351 / 6$ & $348 / 9$ & 409 & $440 / 1$ & $278 / 5$ & $347 / 7$ & $348 / 6$ & 414 & $348 / 5$ & $348 / 4$ \\
\hline $\mathrm{SiO}_{2}$ & 56.14 & 62.44 & 63.48 & 63.74 & 61.40 & 57.52 & 60.80 & 63.24 & 61.84 & 61.16 \\
\hline $\mathrm{TiO}_{2}$ & 1.20 & 0.90 & 0.85 & 0.85 & 0.93 & 0.80 & 0.95 & 0.87 & 0.95 & 0.95 \\
\hline $\mathrm{Al}_{2} \mathrm{O}_{3}$ & 16.52 & 16.48 & 15.97 & 16.04 & 16.03 & 17.61 & 16.77 & 16.00 & 17.73 & 17.68 \\
\hline $\mathrm{Fe}_{2} \mathrm{O}_{3}$ & 2.64 & 1.65 & 2.27 & 2.03 & 2.52 & 2.68 & 1.80 & 2.27 & 1.73 & 2.00 \\
\hline $\mathrm{FeO}$ & 6.84 & 3.97 & 3.68 & 3.51 & 4.11 & 4.19 & 4.88 & 3.58 & 4.15 & 4.28 \\
\hline $\mathrm{MnO}$ & 0.16 & 0.19 & 0.20 & 0.20 & 0.16 & 0.17 & 0.16 & 0.18 & 0.15 & 0.15 \\
\hline $\mathrm{MgO}$ & 3.86 & 2.10 & 1.99 & 1.88 & 2.16 & 2.82 & 2.37 & 2.87 & 2.94 & 2.99 \\
\hline $\mathrm{CaO}$ & 6.21 & 4.88 & 4.34 & 4.41 & 5.29 & 6.92 & 5.19 & 5.19 & 4.37 & 4.58 \\
\hline $\mathrm{Na}_{2} \mathrm{O}$ & 2.80 & 4.61 & 4.74 & 5.02 & 4.53 & 3.68 & 4.46 & 4.46 & 4.24 & 4.24 \\
\hline $\mathrm{K}_{2} \mathrm{O}$ & 1.31 & 1.95 & 1.93 & 2.03 & 1.73 & 1.33 & 1.84 & 1.84 & 1.75 & 1.75 \\
\hline $\mathrm{H}_{2} \mathrm{O}^{-}$ & 0.40 & 0.36 & 0.34 & 0.39 & 0.34 & 0.36 & 0.34 & 0.34 & 0.20 & 0.16 \\
\hline $\mathrm{H}_{2} \mathrm{O}^{+}$ & 1.25 & 0.31 & 0.37 & 0.31 & 0.78 & 0.14 & 0.20 & 0.20 & 0.17 & 0.39 \\
\hline $\begin{array}{l}\mathrm{P}_{2} \mathrm{O}_{5} \\
\text { Ignition }\end{array}$ & 0.21 & 0.09 & 0.18 & 0.16 & 0.29 & 0.30 & 0.29 & 0.29 & 0.23 & 0.12 \\
\hline loss & & & & & & 1.08 & & & & \\
\hline Total & 99.54 & 99.98 & 100.34 & 100.57 & 100.27 & 99.60 & 100.05 & 100.05 & 99.85 & 100.45 \\
\hline
\end{tabular}

1, Analyses were made at the Central Chemical Laboratory of the Institute of Volcanology, Analysts: L. G. Baitsaeva, N. G. Gusakova, T. V. Dolgova, L. A. Kartashova, G. F. Knyazeva, G. V. Lets, G. P. Novoseletskaya, T. G. Osetrova. 2, Analyses of tephra and lava within indicated subdivisions are given in age sequence. 3, See lava and tephra analyses of historical eruptions in Ivanov B. V., 1970; Khrenov et al., 1982. 4, Analysis SL-12 presented to authors by O. B. Selyangin

in character to the activity during beginning of the $\mathrm{KM}_{1}$ interval: many weak eruptions following each other in rapid succession. Within a general sequence of gray weakly stratified coarse ash, some of these eruptions are represented by separate intercalated gray volcanic sand and pumice $\left(\mathrm{PM}_{4}\right.$ and $\left.\mathrm{PM}_{5}\right)$; volume of the materials is $0.01-0.001 \mathrm{~km}^{3}$. In the same stage, lava flows of groups V, VI, and VII were erupted, with volumes of $0.025,0.012$, and $0.02 \mathrm{~km}^{3}$, respectively. They form the upper lava flows on the southern flanks of the volcano. The $\mathrm{IKM}_{2}$ stage culminated with an explosive eruption of scoria about 2800 B.P. Bombs and lapilli of this scoria cover the volcanic cone and its flanks; their thickness reaches 1-1.4 $\mathrm{m}$ close to the volcano. This scoria 


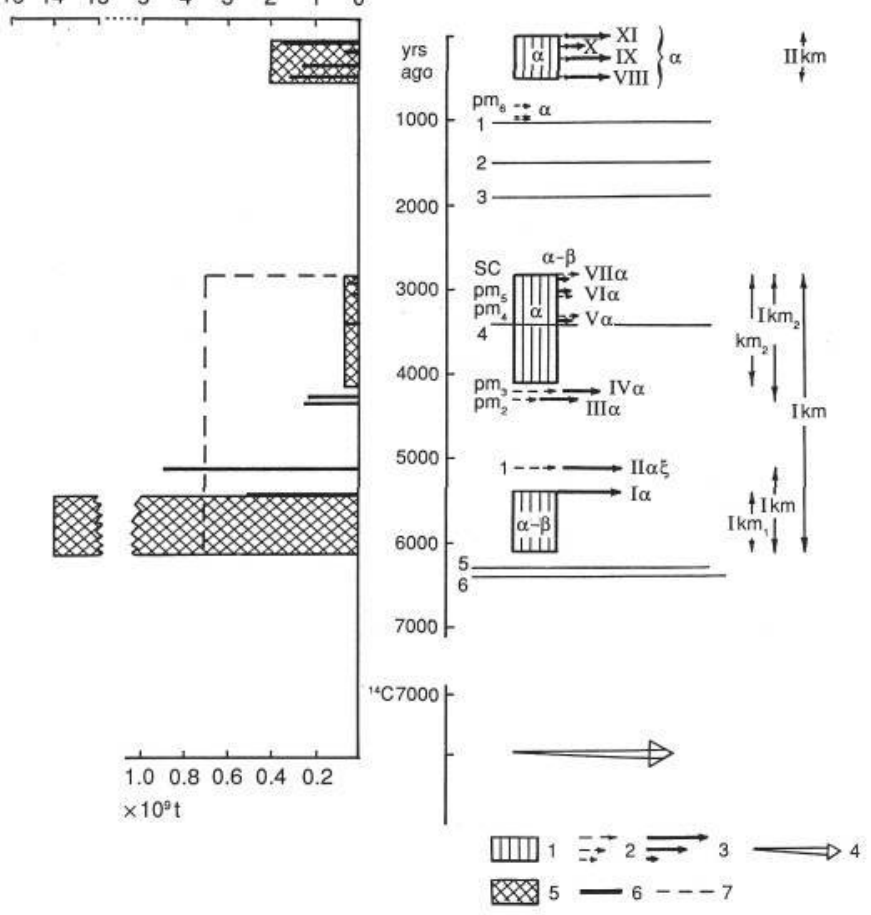

Fig. 5. Eruption dynamics of Karymsky volcano. 1, phases of intense explosive activity; 2, separate explosive eruptions, with volumes: a, 0.1-0.05 km ; b, 0.05-0.01 km; $\mathrm{c}, 0.01-0.0001 \mathrm{~km}^{3} ; 3$, lava flow groups, with volumes: a, $0.5-0.25 \mathrm{~km}^{3} ; \mathrm{b}, 0.25-0.05 \mathrm{~km}^{3}$; c, $0.05-0.01 \mathrm{~km}^{3} ; 4$, caldera-forming eruption (not to scale); 5 , eruptive intensities for the major eruptive phases; 6 , total mass erupted during the strongest eruptions; 7 , average eruptive intensity during the IKM cycle. I-XI, age groups of lava flows; $\mathrm{PM}_{1^{-}}$ $\mathrm{PM}_{6}, \mathrm{SC}$, layers of pumice and scoria of separate explosive eruptions. IKM, IIKM: cycles of activity of the volcano; $\mathrm{IKM}_{1}, \mathrm{IKM}_{2}$, eruptive stages of activity within the IKM cycle; $\mathrm{KM}_{1}$ and $\mathrm{KM}_{2}$, eruptive phases; $1-6$, horizons of transitional tephra

cover subdues the surface microrelief of lava flows in the southern flanks. Total volume of the scoria is about $0.015 \mathrm{~km}^{3}$.

During the $\mathrm{IKM}_{2}$ stage, silicic andesite $(59-63 \%$ $\mathrm{SiO}_{2}$ ) gradually gave way to more mafic varieties (57$59 \% \mathrm{SiO}_{2}$ ). Scoria of the final eruption is basaltic andesite. The transition from andesite to basaltic andesite took place virtually without change in eruptive dynamics. A similar lack of change in eruptive behavior characterized the end of the $\mathrm{KM}_{1}$ phase (Fig. 5), when basaltic andesite was, in contrast, abruptly replaced by andesite (Table 1). In both transitions, the eruptive intensity was neither interrupted nor increased.

By the close of the IKM cycle of activity (about 2800 B.P.) the volcanic cone had grown to nearly its present shape. The subsequent prolonged repose period is expressed by a buried soil zone. Some weak explosive eruptions are marked by two layers of coarse andesitic ash and pumice $\left(\mathrm{PM}_{6}\right)$ in the upper part of the soil. Volumes of the tephra from these eruptions are in the range $0.001-0.008 \mathrm{~km}^{3}$. During the volcanic inactivity, vegetated areas enlarged considerably; shrubs covered the flanking lava flows and also the cone itself up to 1000-m elevation.

New activity of the volcano (the IIKM cycle) started about 500 B.P. The volcanic activity become more episodic: separate moderate-strength eruptions, or series of eruptions, were interrupted by short (tens of years) repose intervals, expressed by thin soil horizons. Eruptions were either explosive or effusive-explosive: outbursts produced pumiceous tephra $\left(\mathrm{PM}_{7}-\mathrm{PM}_{8}\right)$ or coarse gray ash, accompanied by the young (VIII, IX) and historical (X, XI) lava flows. The characteristically fresh microrelief of flow surfaces distinguishs it from the 2800 B.P. scoria-covered flows. The strongest eruptions occurred at 400 and 200-250 B.P., and historically in 1961-1981 (Fig. 2) with eruptive volumes of 0.15; 0.12 , and $0.19 \mathrm{~km}^{3}$, respectively.

To generalize, the volume of material erupted was maximal during the initial IKM cycle $\left(\mathrm{IKM}_{1}\right.$ and decreased sequentially later during this cycle. At the beginning of cycle IIKM, productivity increased again by a factor of almost four, but remained lower than during the beginning of cycle IKM. The eruptive volumes during the IIKM cycle have been only half the average for the IKM cycle (Fig. 5, Table 3). Such a trend accords with the general decrease in productivity at many volcanoes with time (Magus'kin et al. 1982). Including the repose periods, after which accumulated energy was released in eruptions, productivity was $2.1 \times 10^{6} \mathrm{t} / \mathrm{a}$ for the IKM cycle, but only $0.4 \times 10^{6} \mathrm{t} / \mathrm{a}$ for the IIKM cycle. Volcano productivity during the IIKM cycle is close to that in the second half of the IKM cycle $\left(0.4 \times 10^{6} \mathrm{t} / \mathrm{a}\right.$ for the $\left.\mathrm{IKM}_{2}\right)$. Thus, the volcano retained its energetic potential at the same level as in the end of the last repose period. The average intensity for the entire history of the volcano (6100 years) is $2 \times 10^{6} \mathrm{t} / \mathrm{a}$, or $1.5 \times 10^{6} \mathrm{t} / \mathrm{a}$ including the preceding repose period.

Interpretation of the past activity permits an approximate forecast of future eruptions. High eruptive activity of the volcano during the last 500 years and increased volumes of erupted magma during the same time in comparison to the second half of the previous IKM cycle (Fig. 5) show that the volcano has not yet completed its cycle of activity. Thus, activity is not likely to stop in the near future. Considering the duration of eruptive phases with intense activity (700-1300 years), we suggest that high rates of volcanic activity will continue for at least the next 200 years. The character of eruptions will be similar: weak to moderately explosive eruptions involving ejection of andesitic tephra (commonly pumiceous) and formation of lava flows. Andesite may be replaced by basaltic andesite, as occurred at the end of the $\mathrm{KM}_{2}$ phase, although the character of eruptions will not change significantly. The volcanic hazards from lava flows will be limited by the caldera boundaries (radius $2.5-5 \mathrm{~km}$ ), and the thickness of tephra within the caldera will be $5-40 \mathrm{~cm}$, reaching $100-120 \mathrm{~cm}$ at the base of the cone downslope from an explosion. At a distance of 4-5 $\mathrm{km}$ beyond the caldera, maximum tephra thickness will reach 20-25 cm, and 2$4 \mathrm{~cm}$ (coarse ash) at a distance of $10 \mathrm{~km}$. 
Table 3. Volumes and masses erupted by Karymsky volcano at different stages of its activity

\begin{tabular}{|c|c|c|c|c|c|c|c|c|c|c|c|c|}
\hline \multirow{2}{*}{\multicolumn{3}{|c|}{$\begin{array}{l}\text { Main events in history } \\
\text { of volcano } \\
\text { (see index values } \\
\text { in Figs. } 2,3 \text { ) }\end{array}$}} & \multirow{2}{*}{\multicolumn{2}{|c|}{$\begin{array}{l}\text { Duration, } \\
\text { years }\end{array}$}} & \multicolumn{2}{|c|}{ Pyroclastics } & \multicolumn{2}{|l|}{ Lavas } & \multicolumn{2}{|c|}{$\begin{array}{l}\text { Total amount } \\
\text { of material }\end{array}$} & \multirow{2}{*}{\multicolumn{2}{|c|}{$\begin{array}{l}\text { Rate of } \\
\text { evacuation } \\
\text { of material } \\
\mathrm{m} \times 10^{6} \mathrm{t} / \mathrm{y}\end{array}$}} \\
\hline & & & & & $\mathrm{V}, \mathrm{km}^{3}$ & $\mathrm{~m} \times 10^{9}, \mathrm{t}$ & $\mathrm{V}, \mathrm{km}^{3}$ & $\mathrm{~m} \times 10^{9}, \mathrm{t}$ & $\mathrm{V}, \mathrm{km}^{3}$ & $\mathrm{~m} \times 10^{9}, \mathrm{t}$ & & \\
\hline & \multirow{3}{*}{ IIKM } & $\mathrm{PM}_{11-12, \mathrm{x}, \mathrm{Ix}}$ & \multirow{3}{*}{\multicolumn{2}{|c|}{500}} & 0.06 & 0.07 & 0.15 & 0.30 & 0.21 & 0.37 & \multirow{3}{*}{$1.9-2.1$} & \\
\hline & & $\mathrm{PM}_{7-10,1 \mathrm{X}}$, VIII & & & $0.07-0.09$ & $0.08-0.1$ & $0.23-0.30$ & $0.50-0.60$ & $0.30-0.39$ & $0.58-0.70$ & & \\
\hline & & $\Sigma$ & & & $0.13-0.15$ & $0.15-0.17$ & $0.38-0.45$ & $0.8-0.9$ & $0.51-0.60$ & $0.95-1.07$ & & \\
\hline \multicolumn{3}{|c|}{$\begin{array}{l}\mathrm{PM}_{6} \text { and coarse ashes of } \\
\text { relative repose period }\end{array}$} & \multicolumn{2}{|r|}{2300} & 0.02 & 0.02 & - & - & 0.02 & 0.02 & & \\
\hline \multirow{7}{*}{ IKM } & \multirow{4}{*}{$\mathrm{IKM}_{2}$} & $\mathrm{KM}_{2}$ & 1300 & \multirow{4}{*}{1500} & 0.17 & 0.24 & 0.06 & 0.13 & 0.23 & 0.37 & 0.3 & \multirow{4}{*}{$0.53-0.57$} \\
\hline & & $\mathrm{PM}_{3}$-IV & & & $0.1-0.15$ & $0.1-0.15$ & 0.05 & 0.11 & $0.15-0.20$ & $0.21-0.26$ & & \\
\hline & & $\mathrm{PM}_{2}$-III & & & $0.03-0.04$ & $0.03-0.04$ & $0.09-0.1$ & $0.20-0.22$ & $0.12-0.13$ & $0.24-0.26$ & & \\
\hline & & $\sum$ & & & $0.30-0.36$ & $0.37-0.43$ & $0.20-0.21$ & $0.44-0.46$ & $0.50-0.56$ & $0.82-0.89$ & & \\
\hline & \multirow{3}{*}{$\mathrm{IKM}_{1}$} & $\mathrm{PM}_{1}$-II & & \multirow{3}{*}{1000} & 0.1 & 0.1 & 0.4 & 0.8 & 0.5 & 0.9 & & \multirow[t]{3}{*}{$10.4-10.9$} \\
\hline & & $\mathrm{KM}_{1}$ & 700 & & & & & & 4.7 & $9.5-10$ & $13.6-14.3$ & \\
\hline & & $\sum$ & & & & & & & 5.2 & $10.4-10.9$ & & \\
\hline$\Sigma$ & IKM & & & 2500 & & & & & $6.23-6.38$ & $11.22-11.79$ & $3.4-3.6$ & \\
\hline$\Sigma$ & $\mathrm{KM}$ & & & 5300 & & & & & 6.3 & 12.5 & 2 & \\
\hline
\end{tabular}




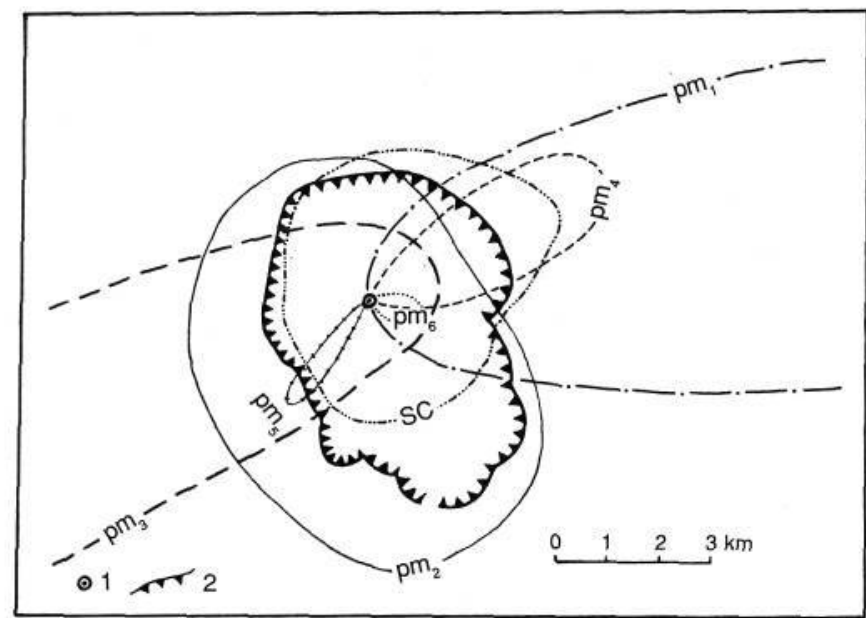

Fig. 6. Distribution of tephra during the main explosive eruptions (bounded by the 10-cm isopach). 1, crater of the volcano; 2, caldera rim scarp. Symbols for tephra layers as on Fig. 2

We suggest that the the discharge rate will eventually decrease, as it did during the second half of the IKM cycle. Productivity of the complete IIKM cycle will be lower than productivity for the IKM cycle, reflecting a decreasing eruptive capacity of the volcano, and leading to a longer repose interval before the beginning of the next eruptive cycle (IIIKM?), or to the cessation of volcanic activity.

\section{Conclusions}

1. The Karymsky caldera, within which Karymsky volcano is nested, collapsed about $7700{ }^{14}$ C B.P. as a result of eruption of $12.5-16 \mathrm{~km}^{3}$ of pumiceous pyroclastic material. Volumes of the caldera and erupted magma are subequal. The caldera-forming eruption is comparable in style and in composition of ejecta to the 1883 eruption of Krakatau.

2. Karymsky volcano began to grow within the caldera about $5300\left(6100{ }^{14}\right.$ C) B.P., after a 1600 -year repose period. About $6.3 \mathrm{~km}^{3}\left(12.3 \times 10^{9} \mathrm{t}\right)$ of lava and pyroclastics have been erupted since, at an average discharge of $2 \times 10^{6} \mathrm{t} / \mathrm{a}$.

3. Two peak eruptive cycles (IKM, IIKM) were separated by 2300 years of low activity. The initial stage of IKM activity (6100-5100 B.P.) was characterized by the maximum discharge rates, most explosive eruptions, and changes in eruptive compositions from basaltic andesite to dacite. The second stage of IKM activity (4300-2800 B.P.) was characterized by decreasing intensity of eruptions and by andesitic compositions that changed to basaltic andesite during the final eruption.
4. The IIKM activity, which started about 500 B.P., is characterized by discrete, weak to moderate andesitic eruptions separated by short repose periods.

5 . The most explosive eruptions occurred at 5400, 52005100 , 4300-4200, 400, 250-200 B.P., and in 19621981.

6. Analysis of the eruptive dynamics suggests that high levels of activity of similar character to recent eruptions will continue for at least the next 200 years.

\section{References}

Arslanov KhA (1978) Corrections to radiocarbon ages. Geokhimiya 8:1157-1164 (in Russian)

Braitseva OA, Yegorova IA, Sulerzhitsky LD (1979) Tephrochronological study of the Karymsky Volcano. Vulkanologiya and Seismologiya 1:48-59 (in Russian)

Braitseva OA, Litasova SI (1982) Age of Karymsky and the Maly Semiachik Volcanoes. Vulkanologiya and Seismologiya 3:9296 (in Russian)

Braitseva OA, Melekestsev IV, Flerov GB (1984) Holocene volcanism of the Tolbachik regional zone of scoria cones. In: Great Tolbachik fissure eruption in Kamchatka, 1975-1976. Moscow, Nauka, pp 177-223 (in Russian)

Braitseva OA, Sulerzhitsky LD, Kirianov VYu (1985) Holocene tephra layers in the Eastern Volcanic zone of Kamchatka. Vulkanologiya and Seismologiya 5:80-90 (in Russian)

Braitseva OA, Litasova SI, Sulerzhitsky LD (1989) Radiocarbon dating and palynological study of tephra on flanks of Karymsky and Maly Semiachik Volcanoes. Vulkanologiya and Seismologiya 1:92-96 (in Russian)

Firstov PM, Lemzikov VK, Feofilaktov VD (1978) The seismic regime of Karymsky Volcano in 1975 and several questions on the forecasting of the time of thermal eruptions. B Vokanol Stantsii (Kamchatka) 54:27-34 (in Russian)

Ivanov BV (1970) Eruption of Karymsky Volcano in 1962-65 and volcanoes of the Karymsky group. Moscow, Nauka, 135 p (in Russian)

Khrenov AP, Dubik YuM, Ivanov BV (1982) Eruptive activity of the Karymsky Volcano (1970-1980). Bull Vulkanologiya and Seismologiya 4:29-49 (in Russian)

Kirianov VYu, Yegorova IA, Litasova SN (1986) Volcanic ashes on Bering Island (Komandor Islands) associated with Holocene eruptions in Kamchatka. Vulkanologiya and Seismologiya 6:18-28 (in Russian)

Magus'kin MA, Enman VB, Seleznev BV, Shkred VI (1982) Displacements on Karymsky Volcano from geodetic and photogrammetric data during 1970-1981. Vulkanologiya and Seismologiya 4:42-49 (in Russian)

Masurenkov Yu P (ed) (1980) A volcanic center: structure and dynamics of the Karymsky center. Moscow, Nauka, 298 pp (in Russian)

Newhall CG, Dzurisin D (1988) Historical unrest at large calderas of the world. US Geol Survey Bull 1855, 1108 pp

Polyak BG, Melekestsev IV (1981) Productivity of volcanoes. Vulkanologiya and Seismologiya 5:22-37 (in Russian)

Vlodavets VI (1947) Volcanoes of the Karymsky group. Kamchatsky Volcano station, Trudy 3:3-40 (in Russian) 